\title{
胆囊胆管における laparoscopic surgery の手技と適応
}

\author{
大分医科大学第 1 外科 \\ 北 野 正 剛
}

腹腔鏡下手術は胆石症に対してはいまや第 1 選択といえる．その手技の要点は出来るだけ良好な視 野のもと総胆管を損傷しないよう胆囊壁に沿って切離を進めることである. 視野確保には斜視型の腹 腔鏡が有用である．腹腔鏡下胆襄摘出術の自験例564例の成績では開腹術への移行は10例（1.7\%）で 術前 DIC にて胆襄が描出されなかった 108 例中では $8.0 \%$ を占めていた. その内訳は高度瘾着 4 例, 胆 囊動脈よりの出血 1 例, 総胆管損傷 1 例, 胆襄癌 4 例であった，術後合併症のため開腹を行った症例 は腸間膜血管よりの出血 1 例, 総胆管損傷 1 例, 肝硬変症例における肝床部出血 1 例の計 3 例であっ た。総胆管結石症例 20 例では術前 EST による切石 8 例, T チューブ挿入 6 例, 経胆霓管的切石 3 例, 総胆管 1 次閉鎖およびCチューブ挿入 3 例であった. Tチューブ掩入例では術後約 1 か月の入院が必

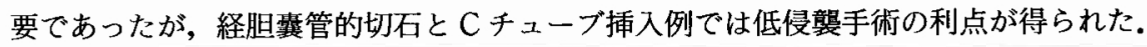

Key words : laparoscopic surgery, gallstones, common bile duct exploration

はじめに

わが国に腹腔鏡下胆賈摘出術がもたらされではや 4 年が経過し, 今や胆襄摘出術の第 1 選択とされる術 式となったといえる，当初は機器の未発達や手技上の 問題点から，胆囊炎による瘾着症例を中心にかなりの ものが適応外として開腹術を余儀なくされたが, 現在 では手技への習熟とともにますます従来の開腹術の適 応に近づいているのが現状である (Table 1)。これに は光学機器として解像度が優れたビデオシステムが開 発され, 肉眼よりも詳細な観察が可能となったことや， 手術器具が改良され開腹術における操作とほほ同じこ とが出来るようになったハード面での充実も大きく寄 与している.したがって腹腔鏡下胆囊摘出術の適応拡
大のみでなく，総胆管結石に対しても種々の腹腔鏡下 手術が応用されるようになった。

本稿では筆者が行ってきた胆囊および総胆管結石症 に対する腹腔鏡下手術の手技と工夫,さらに成績およ び適応について申し述べたい.

\section{腹腔鏡下手術の方法}

腹腔鏡下胆囊摘出術と総胆管手術の手技を述べる.

1. 機器の配置と術者助手の位置

術者とビデオカメラを操作する第 2 助手が患者の左 側に，第 1 助手とナースが右側に立つ（Fig. 1A).

2. 各種器具の操作

手術手技の手順に沿って器具の操作法を述べる。

(1) トラカールの挿入部位

Table 1 Contraindication for laparoscopic cholecystectomy (Ref. 7)

\begin{tabular}{l|l}
\hline \multicolumn{1}{c|}{ Absolute contraindication } & \multicolumn{1}{c}{ Relative contraindication } \\
\hline Severe bleeding tendency & Portal hypertension \\
Septic panperitonitis & CBD stones \\
Acute cholangitis & Acute cholecystitis \\
High risk for general anaesthesia & Previous abdominal surgery \\
Jaundice & Pregnancy (selective cases) \\
\hline
\end{tabular}

*第24回・Laparoscopic Surgery

$<1994$ 年 6 月 8 日受理 >別刷請求先：北野 正剛

₹ 879-55 大分郡㣣間町医大々丘 $1-1$ 大分医科大

学第 1 外科 
Fig. 1A Operating room layout

$\mathrm{S}$ : Surgeon A: Anesthetician $\mathrm{A}_{1,2}$ : Asisstants $\mathrm{M}_{1,2}$ : Monitors $\mathrm{N}$ : Nurse $\mathrm{P}$ : Pneumatic apparatus E: Electro-coagulator

Fig. 1B Sites of trocars
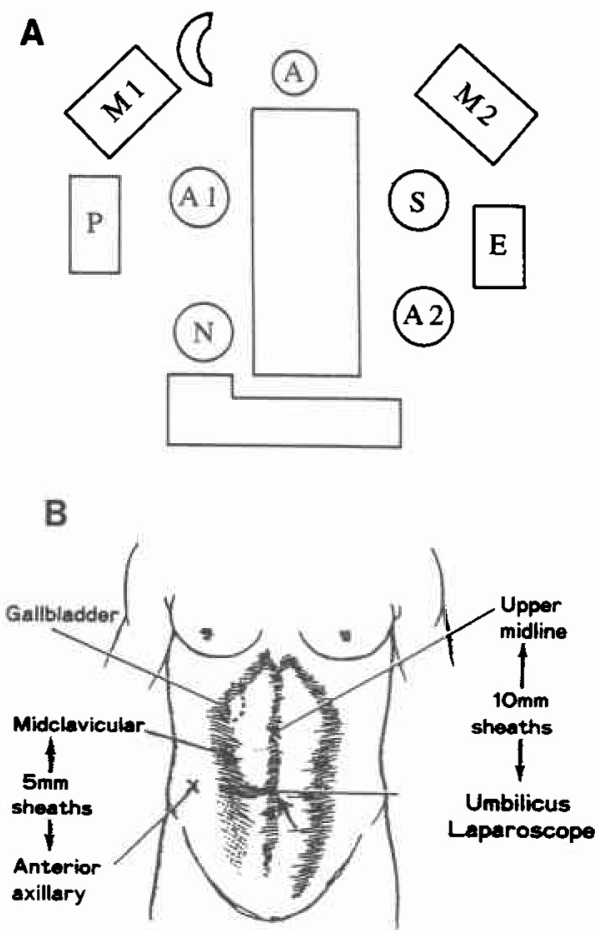

Verres 針による穿刺法に比べてより安全な Open laparoscopy を用いる。すなわち臍輪下部に $1 \mathrm{~cm}$ 強の 切開を置き腹膜まで少し切開して先端が鈍のトラカー ルを挿入し炭酸ガスを注入する．腹腔鏡を挿入し観察 下に他の 3 本のトラカールの位㯰を決め挿入する (Fig. 1B).

\section{(2) 腹腔鏡}

斜視型腹腔鏡の使用を勧めたい. 直視型に比べて腹 腔鏡を回転させるので，操作に慣れないと視野も同時 に回転して手術操作に困難を覚えるが, 少し慣れると 術野をいろいろな角度から観察できるので胆亯管の剥 離には大変有用である。また総胆管手術には術野をの ぞきこめる点で必須といえる。

(3) 鉗子類

術者が 1 本のみの鉗子を操作する方法は, 鉗子先端 の動きが微細に調節できるので, 手技修得の初期段階 では用いても良いが, 術者が 2 本の鉗子を操作するほ うが後に複雑な操作となるAdvanced surgery の修得
Fig. 2 GCP forceps. This dissector has three functions; Grasping, Cutting and Parting the tissues.

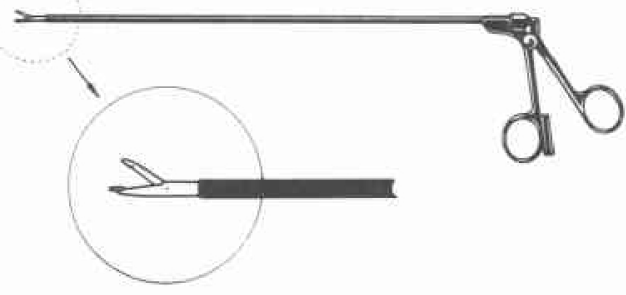

Fig. 3 U-shaped retractor elevation of the abdom inal wall for laparoscopic cholecystectomy

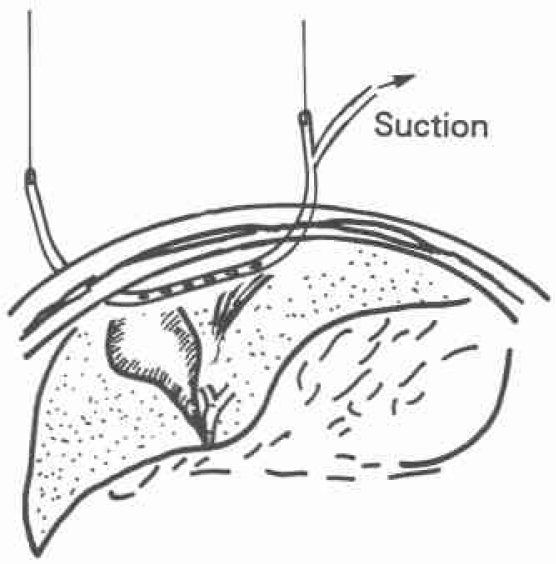

のためにも良いと考えられる。フックやへラなどを用 いて剥離を進める。われわれは手術の操作一組織の把 持, 鋭的鈍的剥離および電気凝固一が 1 本で出来る GCP 鉗子 (Grasping, Cutting, Parting) ${ }^{2)}$ を作成し, 手技の簡素化を図っている（Fig. 2).

(4) 超音波メス

血管や胆管などの硬い組織を残して脂肪組織などの 柔らかい組織を先端の振動ブレードで乳化させるの で, 安全な剥離操作が可能となる。癒着症例において 威力を発揮する。

(5) 腹壁吊り上げ法

気腹の代わりに腹壁を吊り上げることにより視野を 確保する方法である。筆者は癒着症例や高齢者にはU 型リトラクター ${ }^{3)}$ (Fig. 3) を頻用している。心循環器 系に負担が少なく, 切開創も通常のトラカール大から 適宜手技の困難さに応じて追加切開が可能で, 通常の 手術用鉗子類が使える利点がある。

3. 胆囊摘出の手技 
Fig. 4 Initial approach for laparoscopic dissection of the diseased gallbladder

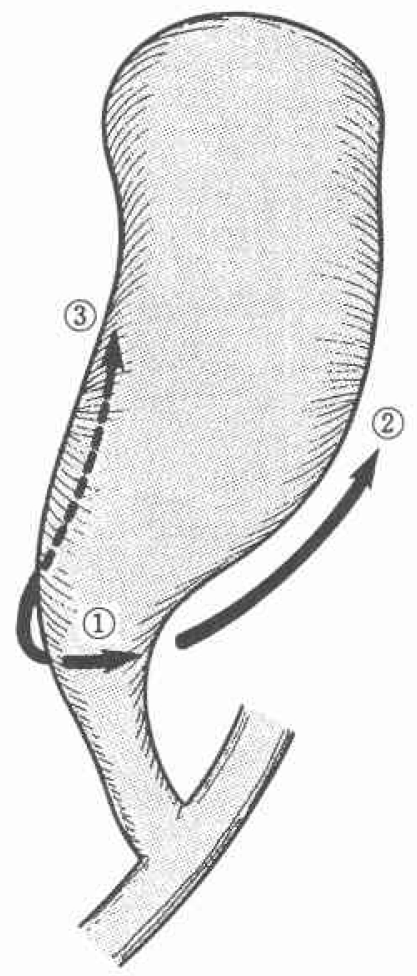

(1) 胆囊管の剥離と切離

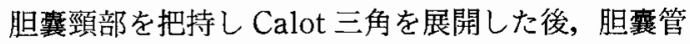
前面の胆囊頚部から胆囊管への移行部の墏膜を先細の 鎮子で摘み，電気凝固で剥離を進める(Fig. 4). 胆翼 頸部の後面を肝表面近くまで先細の GCP 鋁子などを 用いて少しずつ剥離を進めると胆囊管が持ち上がる. 胆哄頸部近くで左右両面から剝離を進め胆囊管を遊離 する，胆囊管が十分剥離されたらクリップにて胆襄管 を処理する。胆囊管が肥厚している場合は体外結紫 法4を用いて結紮し切離する。

(2) 術中胆道造影

胆囊管へのカテーテル挿入手技の修得目的と術前 DICにて胆襄が描出されない症例に適宜胆囊管より の胆道造影を施行していている。

(3) 胆囊動脈の処理

われわれは通常胆囊動脈の本幹の剥離はあまり行わ ない. 胆囊寄りで剥離し，かつ GCP 鉗子で胆囊動脈の 分枝をしっかり㨡み，電気凝固させ切離することが多 ᄂ).

(4) 肝床部よりの剥離
Table 2 Surgical management of CBD stones

\begin{tabular}{c} 
Preoperative EST \\
Transcystic removal \\
DBD Exploration \\
T-tube insertion \\
C-tube indertion \\
\hline
\end{tabular}

胆囊の獎膜を剥離した磻を肝床部へと剥離を進め る.肝床部からの出血は丁寧に電気凝固止血し, 必要 であればフィブリン糊を使用する。

(5) 胆囊の取り出し

胆囊壁に炎症があったり，胆石が大きい場合は胆囊 頸部を切開し胆汁を吸引した後モニターで観察しなが らペアン鉗子で胆褰内の結石を砕くと取り出し容易と なる．臍下部の切開創から取り出すのも良い.

(6) 洗浄

少量でも出血や胆汁が漏れたときには洗浄水が透明 になるまで洗浄する.コック式のものよりトランペッ トタイプが使いやすい.

(7) ドレーンの留置

あらかじめ上腹部正中のトラカールの先端を肝門部 まで誘導しておき，剩離釷子でペンローズドレーンの 先端近くをはさみモニターを見ながら一気に挿入す る。剩離錙子ではさんだままトラカールを鉗子に沿っ て引き抜いたあと, ドレーンを離しゆっくり鉗子を抜 $<$.

4. 総胆管結石に対する手術手技

種々の方法が報告されている（Table 2)，経内視鏡 的乳頭切開 (EST) および切石術の不成功例に腹腔鏡 下に総胆管へアプローチする。

(1) 経胆囊管的アプローチ

胆霊管に拡張が見られる場合，バルーンなどを用い

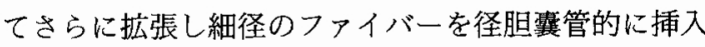
し種々の器具で砕石する。バスケット鉗子による切石, 電気水圧破砝装置，レーザー破砕による方法がある。

(2) 総胆管切開

結石が大きめで個数が多くなれば総胆管切開が必要 となる.切開部より胆道鏡下にバスケット鉗子で結石 を除去する．肝内結石や遺残結石などがなければ総胆 管は結節縫合による Primary closure を行い胆囊管か らいわゆるCチューブを挿入し，弾性系で結禁すると 5 日ほどで抜去できる(Fig. 5). 結石多数例や遺残結 石が疑われる場合は Tチューブを挿入, 術後の検索お よび胆道内視鏡下の処置を講じる．Tチューブの挿入 
Fig. 5 C-tube insertion following CBD exploration

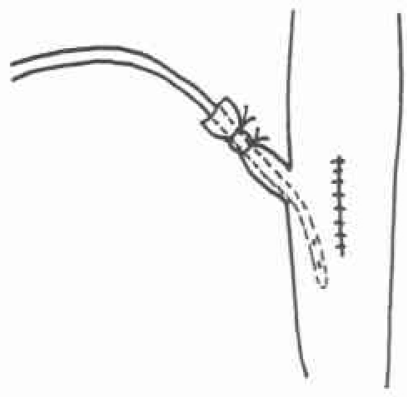

には径 $10 \mathrm{~mm}$ のオーバーチューブを使用すると手技が 容易となる5 . 癒着が強い場合や結石がさらに多数で 嵌頓しているような場合は腹壁吊り上げ法に変え ${ }^{6)}$, 小切開を加元開腹術の操作と同様に行う.

\section{成 績}

急性腹膜炎合併例や明らかな胆襄癌症例を除いた 535例に腹腔鏡下胆虽摘出術を施行した。開腹術への移 行は10例 $(1.7 \%)$ で術前 DICにて胆囊が描出されな かった108例中では $8.0 \%$ 占めていた。その内訳は高 度癒着 4 例, 胆裳動脈よりの出血 1 例, 総胆管損傷 1 例, 胆囊癌 4 例であった.術後合併症のため開腹を行っ た症例は腸間膜血管よりの出血 1 例, 総胆管損傷 1 例, 肝硬変症例における肝床部出血 1 例の計 3 例であっ た. 総胆管結石症例20例に対し腹腔鏡下手術を施行し た.術前 ESTによる切石 8 例, 総胆管切開 Tチューブ 挿入 6 例, 経胆囊管的切石 3 例, 総胆管切開 1 次閉鎖 およびCチューブ插入 3 例であった。いずれも, 特別 な合併症なく退院となった， Tチューブ挿入例では術 後約 1 か月の入院が必要であったが, 経胆囊管的切石 とCチューブ挿入例では Minimally invasive sur- geryの利点が得られた。

$$
\text { 考察 }
$$

腹腔鏡下胆䧶摘出術の成績に関しては多くの報告が

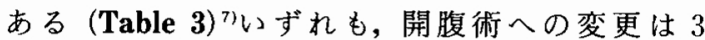
〜 $5 \%$, 合併症としても 1 〜 $2 \%$ と安全な手技である ことを表している.ただこれはいずれも多数例を経験 した施設からの報告であり，新たに本手術を始めた施 設で経験が少ない時点で総胆管離断などの合併症もま れではないようであるので, 開始当初は特に慎重なる 操作が肝要である.ついで現時点での種々の手技の適 応と選択について述べる。

\section{1. 胆襄結石}

従来の待期的開腹術の適応とほとんど同様と考えて 良い.

\section{2. 総胆管結石}

結石の大ささと個数により術前内視鏡的砕石術，経 胆襄管的砕石と総胆管切開のいずれかが選択される。 内視鏡的乳頭切開砕石：第 1 選択とする。

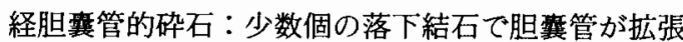
している場合は経胆道鏡的にバスケット鉗子などを用 いて切石する。

総胆管切開：結石が大で多数の場合は総胆管切開を 行い十分な切開口より結石を摘出する。その後は $\mathrm{C}$

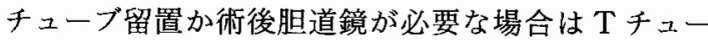
ブ挿入を行う。

\section{文献}

1）山川達郎, 酒井 滋, 石川泰郎ほか：腹鏡下胆粪摘 出術の手技. 臨外 45:125-1259, 1990

2) Kitano S, Tomikawa M, Iso $Y$ et al: A safe and simple method to maintain a clear field of vision during laparoscopic cholecystectomy. Surg Endosc 6 : 197-198, 1992

3) Kitano $S$, Iso $Y$, Moriyama $M$ et al: A newly-

Table 3 Documenyed results of laparoscopic cholecystectomy(Ref. 7)

\begin{tabular}{l|r|c|c|c}
\hline & No. pts & $\begin{array}{c}\text { Conversion } \\
\text { rate(\%) }\end{array}$ & $\begin{array}{c}\text { Complication } \\
\text { rate(\%) }\end{array}$ & $\begin{array}{c}\text { Bile duct injury } \\
\text { (including cystic } \\
\text { duct injury)(\%) }\end{array}$ \\
\hline Cushieri & 1,236 & 3.6 & 1.6 & 0.32 \\
Voyles & 453 & 5.3 & & 0.22 \\
Berci & 418 & 5.3 & & 0.48 \\
Bailey & 375 & 5.3 & 3.5 & 1.6 \\
Davis & 622 & 4.2 & 3.8 & 0.32 \\
The Southern Surgeons Club & 1,518 & 4.7 & 5.1 & 0.5 \\
Larson & 1,983 & 4.5 & 2.1 & 0.25 \\
Kimura & 1.989 & 2.7 & 1.75 & 0.55 \\
\hline
\end{tabular}


designed single dissector useful for laparoscopic cholecystectomy. Surg Endosc 6: 144-146, 1992

4) Kitano S, Moriyama M, Sugimachi K : A simple and rapid technique for suture ligation during laparoscopic cholecyst ectomy. Surg Laparosc Endosc 2 : 321-322, 1992

5) Kitano $S$, Iso $Y$, Moriyama $M$ et al : A rapid and simple technique for insertion of a $\mathrm{T}$ tube into the minimally incised common bile duct at lapraroscopic surgery. Surg Endosc 7 :
104-105, 1993

6) Kitano $\mathrm{S}$, Iso $\mathrm{Y}$, Tomikawa $\mathrm{M}$ et al: A prospective randomized trial comparing pneumoperitoneum and U-sh retractor elevation for laparoscopic cholecy stectomy. Surg Endosc 7:311-314, 1993

7) Kitano S, Sugimachi K: Laparoscopic cholecystectomy has opened the door to minimally invasive surgery. $\mathrm{J}$ Gastroenterol Hepatol 8:476-482, 1993

\section{Laparoscopic Surgery in the Management of Gallstones}

\section{Seigo Kitano \\ Department of Surgery I, Oita Medical University}

In the surgical treatment of a diseased gallbladder, laparoscopic cholecystectomy has gained a world-wide popularity since 1989, with the advantages of less pain, good cosmesis, short hospital stay and early ecovery. Since 1990, 564 laparoscopic cholecystectomies have been carried out in our institution. The rate of convertion to open surgery is about $3.5 \%$ and the postoperative complications occurred in 3 of the patients; a bleeding from the mesenteric vessel, $\mathrm{CBD}$ injury and a bleeding from the cirrhotic liver bed. The more complicated procedures have been done in some of the selected institutions. In case of CBD exploration, we used a $\mathrm{C}$-tube to be inserted into the cystic duct following primary closure of the CBD, instead of a T-tube.

Reprint requests: Seigo Kitano Department of Surgery I, Oita Medical University

1-1 Idaigaoka, Hasama-machi, Oita, 879-55 JAPAN 